\title{
Financial management in Czech enterprises depending on their size
}

\author{
Irena HONKOVÁ \\ ${ }^{1}$ University of Pardubice, Pardubice, Czech Republic \\ Irena.honkova@upce.cz
}

\begin{abstract}
This text aims to present the latest knowledge of enterprise practice within the financial management sphere. This text contains following information: who in the company serves as the financial manager, what is the most common way of financing, what is the most frequent method of investment evaluation, what financial plans the enterprises prepare and what information is used by enterprises in accounting statements. The research has shown that there are two different groups. The first group includes micro and small companies that are financially managed by their owner, or their executive manager. The second group includes middle and large companies having their own financial manager. In addition it was found that the foreign capital belongs to the most frequently used form of financing only for small companies. The research has also found that a great portion of companies does not use any method of investment evaluation. The payback period and net current value belong among the most frequently used methods. It was also found that short-term financial plan is the most often used one. As for the balance informational function, all companies, regardless their size, use this statement for their assets management, on the contrary the profit and loss statement is used as the most often information for operational costs management across companies of all sizes. The presented research has confirmed several statements that could be expected nevertheless it also found new information or detailed the current one.
\end{abstract}

Keywords: Financial management, financial planning, methods of investment evaluation.

\section{Introduction}

This text aims to present the latest knowledge of enterprise practice within the financial management sphere. This text contains following information: who in the company serves as the financial manager, what is the most common way of financing, what is the most frequent method of investment evaluation, what financial plans the enterprises prepare and what information is used by enterprises in accounting statements.

This paper based on an own questionnaire survey and so it can describe actual situation in financial management in the Czech Republic. All type of businesses across the country were addressed. 


\section{Statement of a problem}

The first problem was to determine what a business is. An enterprise may be associated with a legal person, but it may also be tied to an entrepreneur - an individual. [18]. During the questionnaire survey, a problem arises that many respondents do not compile a balance sheet, a profit and loss statement, and cash flow. Some people set up a balance sheet and a profit and loss statement, but not a cash flow statement. As a result of the statistical calculations, these respondents had to be taken into account while not excluding them from the research, as this would affect the results. The author has assigned the task of mapping all businesses, so called micro enterprises as well.

\subsection{Financial management tasks}

The company financial management (financial management) has four main tasks $[17,3,5,14]$ :

- To provide the capital for common as well as extraordinary needs of the company and to decide on its structure and structure changes, i.e. on activities related to liabilities shown in the balance,

- To decide on capital allocation, i.e. activities related namely to assets in the balance, based on methods for investment decision-making,

- To decide on the profit distribution,

- To predict, plan, note, analyse, check and manage the economic part of the company so that its financial stability is assured, which in fact means the capability of the company to pay its liabilities.

\subsection{Ownership separated from the financial management}

The author of this article does not primarily rank the profit distribution among financial management competencies. In the same way, some principal decisions within the scope of financing or capital allocations can belong to the competency of a higher body. Thus it is important to state that the financial manager tasks depend on the competency of that persons who performs such position.

In the vast majority of companies the ownership and the company management are separated. Only in case of smaller companies the owner or some of owners also manages the company [2]. The separation of ownership and company management is namely noticeable in joint stock companies where the shareholders, being the owners, assign some managing authorities to managers, through the Board of directors of the joint stock company [7].

Then the ownership separated from the company management can logically initiate issues due to different interests of owners and managers. The different interests among owners (shareholder) and managers are for example seen in the sphere of longterm and short-term goals conflict, revenue maximizing strategy, over-estimated 
acquisitions, and risks in relations with suppliers, employees and customer and in the different approach of managers and owners to risks [1].

Marek [13] defines the situation in which the owners engage the so-called agents as the so-called costs of representation.

\subsection{Procuring of capital}

As for the financial manager task to provide the capital, the authors Hrdy \& Krechovská [6] state a list of financing kinds based on various points of view. The author believes that own external capital, undistributed profit, supplier credit, financial leasing and bank loans are the form of financing used mostly by every company.

\subsection{Investment evaluation}

As for the financial manager task that consists in the evaluation of potential investment and within the competency scope to decide on its performance the method defined for it should be followed. Besides the simple statistic methods (for example the payback period) there are also advanced methods of investment decision-making that include the factor of time. They include the internal rate of return, rentability index and the net current value $[4,8,9,11,16]$.

\subsection{Financial planning}

The financial management is performed through a financial plan.

The financing planning differs based on the size of company. While in large companies the financial planning has its strong position among particular company processes, linked to strategic concepts and with defined organisational as well as time course, it is scheduled rather at its operative level in smaller companies [6].

\section{Methods}

\subsection{Respondents selection}

During the first half of 2018660 questionnaires concerning the financial management were received. The questionnaire asked about the size of company (based on the company classification in the Directive for entrepreneurs [19, 21]), financial manager person, most often way of financing, investment evaluation methods, financial plans and use of information based on accounting statements. 202 questionnaire were erroneous and thus they had to be eliminated. Thus 458 questionnaires were processed of which 182 were from micro companies, 144 are small companies, 84 middle companies and 48 large companies. 


\subsection{Data selection}

202 questionnaire were erroneous and thus they had to be eliminated. Thus 458 questionnaires were processed of which 182 were from micro companies, 144 are small companies, 84 middle companies and 48 large companies.

\subsection{Hypothesis}

Based on the chapter 2 following hypothesis were defined:

- H1: in small companies the financial manager person is also the company owner, whereas in larger companies such person is separated from the owner,

- H2: way of company financing independent of the company size,

- H3: the use of investment decision-making methods is independent of the fact whether the company prepares their long-term financial plan,

- H4: companies that prepare their long-term financial plan also prepare their shortterm financial plan,

- H5: the use of information from the balance does not depend on the company size,

- H6: the use of information from the profit and loss statement does not depend on the company size.

\subsection{Research Methods}

The questionnaires were processed with the program Excel, using the contingency table function [10,12] and frequency function [12] and the independency test was also performed [12] because of non-compliance with the assumption of normal distribution.

The independency test belongs among non-parametric tests unless the division normality presumption is fulfilled [20]. But it has its limits and thus could not be used in all intended examples.

The independency test is based on real received data from which the expected values are calculated. These two matrices are subsequently compared and the sum of their variations means the value for statistic testing.

The independency test limits are based on the presumption that the expected joint frequencies shall be higher than 5 (some texts present the requirement for joint frequencies above 1 and minimally $80 \%$ of all joint frequencies higher than 5) [12].

The further limit consists in the fact that no zero can be in any place of numbers of really received frequencies because, when comparing the real and expected values, the frequency of real values frequency is in the denominator and thus it wold not be possible to perform the calculation.

As for the results of performed research the questionnaire structures are divided in following five groups: financial manager person, the most often way of financing, methods of investment evaluation, financial plans and use of information contained in accounting statements. Following sub-chapters statistically analyse individual groups and in some case the possible dependency among them is searched. 


\section{$4 \quad$ Research results}

As for the results of performed research they are divided, based on the above stated hypothesis, in following five groups: financial manager person, the most often way of financing, methods of investment evaluation, financial plans and use of information contained in accounting statements. Following sub-chapters statistically analyse individual groups and in some case the possible dependency among them is searched.

\subsection{Financial manager person}

The respondents were asked to state what person in their company is most devoted to the financial management. They had following options to choose: external company (consultant), external accountant, financial director (economist), general director, internal accountant, executive manager and owner. The Table 1 show the frequency of particular responses based on the company size.

Table 1. Contingency table Financial manager person based on the company size.

\begin{tabular}{|l|l|l|l|l|}
\hline Person & $\begin{array}{l}\text { Micro } \\
\text { company }\end{array}$ & $\begin{array}{l}\text { Small } \\
\text { company }\end{array}$ & $\begin{array}{l}\text { Middle } \\
\text { company }\end{array}$ & $\begin{array}{l}\text { Large } \\
\text { company }\end{array}$ \\
\hline $\begin{array}{l}\text { External company } \\
\text { (consultant) }\end{array}$ & 2 & 0 & 0 & 1 \\
\hline External accountant & 4 & 0 & 0 & 0 \\
\hline $\begin{array}{l}\text { Financial director } \\
\text { (economist) }\end{array}$ & 8 & 13 & 42 & 35 \\
\hline General director & 0 & 4 & 6 & 3 \\
\hline Internal accountant & 4 & 15 & 8 & 3 \\
\hline Executive manager & 45 & 47 & 14 & 1 \\
\hline Owner & 134 & 55 & 12 & 2 \\
\hline
\end{tabular}

It results from the table above that in larger companies there are financial economists whereas in micro and small companies the owner, or the executive manager performs the function of financial manager.

\subsection{Most often way of financing}

The respondents were asked to choose the most often way of financing from following: bank loan, supplier credit, financial leasing, undistributed profit, own external. The frequency of answers is shown in the Table 2. The bank loan and own external capital belong among the most often used way of financing.

Table 2. Contingency table The most often way of financing based on the company size

\begin{tabular}{|l|l|l|l|l|l|}
\hline $\begin{array}{l}\text { The most often way of } \\
\text { financing }\end{array}$ & $\begin{array}{l}\text { Micro } \\
\text { company }\end{array}$ & $\begin{array}{l}\text { Small } \\
\text { company }\end{array}$ & $\begin{array}{l}\text { Middle } \\
\text { company }\end{array}$ & $\begin{array}{l}\text { Large } \\
\text { company }\end{array}$ & Total \\
\hline Bank loan & 42 & 52 & 35 & 13 & 142 \\
\hline
\end{tabular}




\begin{tabular}{|l|l|l|l|l|l|}
\hline Supplier credit & 4 & 5 & 2 & 1 & 12 \\
\hline Financial leasing & 13 & 26 & 18 & 5 & 62 \\
\hline Undistributed profit & 28 & 28 & 32 & 15 & 103 \\
\hline Own external & 86 & 23 & 15 & 15 & 139 \\
\hline
\end{tabular}

In addition, the dependency of company size on the preferred way of financing was investigated using the independency test. At the importance level $95 \%$ (note: this level was defined for all test hypothesis) it was calculated that the value of test criterion belongs into the critical zone. Thus the hypothesis of independency was refused and it was proven that the company size influences the way of financing.

\subsection{Methods of investment evaluation}

The Figure 1 shows the apportionment of investment evaluation methods. The respondents were asked to choose the most often used method for investment effectiveness evaluation from the following: net current value ( $\breve{C} \mathrm{SH})$, payback period (DN), rentability index (IR), internal rate of return (VVP) or other. They also could choose that no method is used.

The performed research showed that $34 \%$ of companies do not use any method for evaluation of their investments. The most often used method consists in the statistic method of investment payback used by $22 \%$ or respondents. $17 \%$ use the net current value.

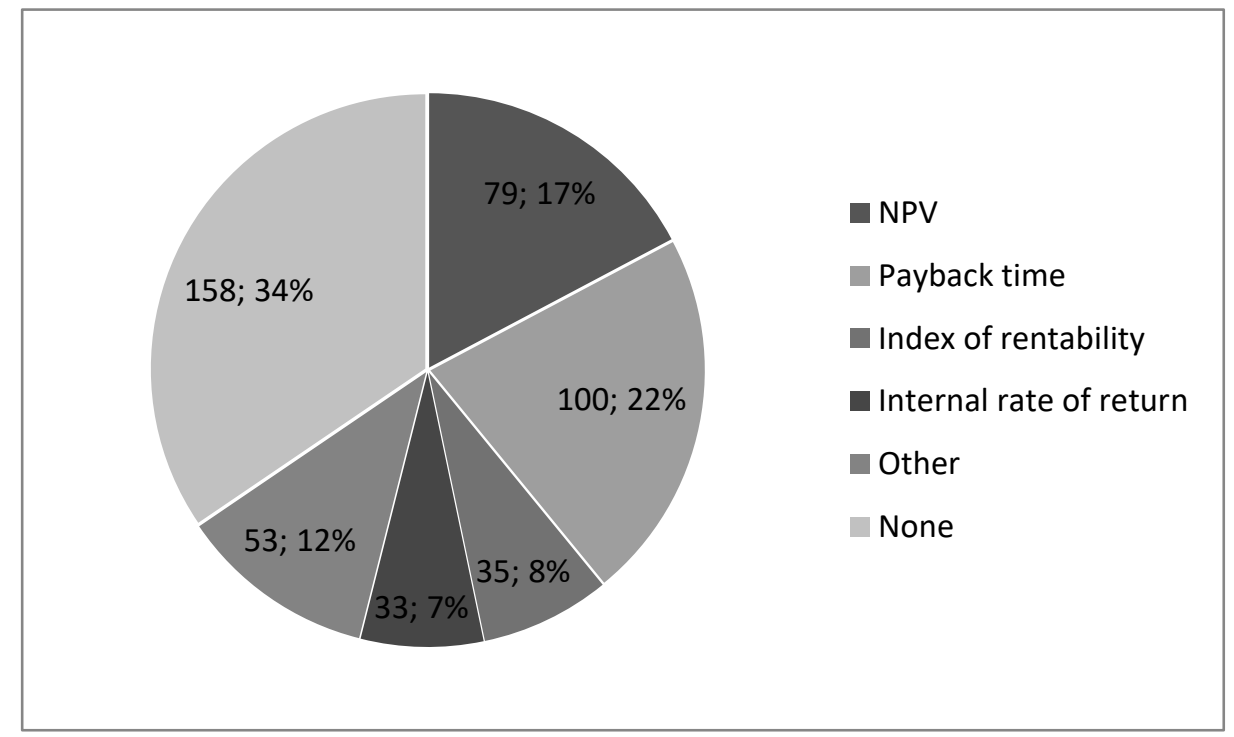

Fig. 1. The most often used methods of investment evaluation.

With regard to the fact that the investment decision-making belongs among the long-term financial plans it was tested using the independency test in order to check whether the chosen methods relate to the fact that the company prepares its 
long-term plan. It was statistically found that the use of investment evaluation method really relates (in positive way) to the preparation of long-term financial plan. On the contrary companies that do not prepare any long-term plan usually do not use any methods of investment evaluation.

\subsection{Financial plans}

Another task for the respondents was to answer whether they prepared any operative plan, any short-term or long-term plan. For the purpose of clear understanding it was explained that the operative plan is for 1-3 months, the short-term plan is for 3-12 months and the long-term plan is for the period longer than 1 year. The number of positive answers, based on the company size, is shown in the Table 3.

Table 3. Companies preparing their financial plans- absolute frequency.

\begin{tabular}{|l|l|l|l|}
\hline Companies & Operative plan & Short-term plan & Long-term plan \\
\hline Micro & 98 & 94 & 54 \\
\hline Small & 90 & 106 & 72 \\
\hline Middle & 61 & 77 & 62 \\
\hline Large & 39 & 44 & 41 \\
\hline Total & 288 & 321 & 229 \\
\hline
\end{tabular}

The Table 4 shows the relative frequency with regard to the total number of respondents in particular sizes of companies. The micro and small companies rather compile their operative and short-term plans whereas the $\mathrm{m}$ idle and large companies often also prepare their long-term financial plans.

Table 4. Companies preparing their financial plans - relative frequency.

\begin{tabular}{|l|r|r|r|}
\hline Companies & Operative plan & Short-term plan & Long-term plan \\
\hline Micro & $68 \%$ & $65 \%$ & $38 \%$ \\
\hline Small & $49 \%$ & $58 \%$ & $40 \%$ \\
\hline Middle & $73 \%$ & $92 \%$ & $74 \%$ \\
\hline Large & $81 \%$ & $92 \%$ & $85 \%$ \\
\hline
\end{tabular}

The independency test also has shown that the companies that prepare their long-term plans also formulate their operative plan as well as that the short-term plan creation is related to the preparation of operative plan. 


\subsection{Use of data from accounting statements}

The last part of the questionnaire was aimed to find out whether the data from accounting statements are used by companies for the purpose of financial management. The following tables 5, 6, 7 show the summary of research results within these statements: balance, profit and loss statement, cash flow statement.

Table 5. Use of data from the balance - based on the company size

\begin{tabular}{|l|l|l|l|l|l|}
\hline Kind of information & $\begin{array}{l}\text { Micro } \\
\text { company }\end{array}$ & $\begin{array}{l}\text { Small } \\
\text { company }\end{array}$ & $\begin{array}{l}\text { Middle } \\
\text { company }\end{array}$ & $\begin{array}{l}\text { Large } \\
\text { company }\end{array}$ & Total \\
\hline $\begin{array}{l}\text { Management of time } \\
\text { assets and liabilities } \\
\text { structure }\end{array}$ & 61 & 62 & 54 & 44 & 221 \\
\hline $\begin{array}{l}\text { Capital structure } \\
\text { management }\end{array}$ & 16 & 17 & 8 & 1 & 42 \\
\hline Assets management & 105 & 65 & 22 & 3 & 195 \\
\hline
\end{tabular}

It results from the Table 5 that the companies most often use the data from the balance to manage the time assets and liabilities structure whereas the micro companies emphasize the assets management. It results from the statistic independency test that the informational balance character depends on how big the company is.

Table 6. Use of profit and loss statement data - based on the company size

\begin{tabular}{|l|l|l|l|l|l|}
\hline Kind of information & $\begin{array}{l}\text { Micro } \\
\text { company }\end{array}$ & $\begin{array}{l}\text { Small } \\
\text { company }\end{array}$ & $\begin{array}{l}\text { Middle } \\
\text { company }\end{array}$ & $\begin{array}{l}\text { Large } \\
\text { company }\end{array}$ & Total \\
\hline Margin optimizing & 11 & 7 & 10 & 8 & 36 \\
\hline $\begin{array}{l}\text { Depreciation } \\
\text { processing }\end{array}$ & 8 & 2 & 0 & 0 & 10 \\
\hline $\begin{array}{l}\text { Revenues } \\
\text { predictions costs }\end{array}$ & 10 & 26 & 15 & 15 & 93 \\
\hline $\begin{array}{l}\text { Wage } \\
\text { management }\end{array}$ & 113 & 94 & 13 & 2 & 40 \\
\hline $\begin{array}{l}\text { Operational costs } \\
\text { management }\end{array}$ & 3 & 0 & 0 & 19 & 272 \\
\hline $\begin{array}{l}\text { Interest } \\
\text { expenditures } \\
\text { management }\end{array}$ & & 46 & 4 & 7 \\
\hline
\end{tabular}

It results from the Table 6 that all companies, regardless their size, unambiguously prefer the operational costs management.

\subsection{Hypothesis testing}

The performed independency tests confirmed or disproved the defined hypothesis as this summary shows: 
Hypothesis H1: the financial manager person is the owner in small companies, whereas in larger companies the separation of the owner was confirmed.

Hypothesis H2: that the way of company financing is independent of the company size was disproved.

Hypothesis H3: that the use of investment decision-making methods is independent of the fact whether the company prepares its long-term financial plan was refused.

H4: that the companies prepare their long-term financial plan, they create also their short-term financial plan, was confirmed.

H5: that the use of the balance data is independent on the company size was confirmed.

H6: that the use of the profit and loss statement data is independent on the company size was confirmed.

\section{Conclusion}

This text aimed to present the latest knowledge of enterprise practice within the financial management sphere. This text contains following information: who in the company serves as the financial manager, what is the most common way of financing, what is the most frequent method of investment evaluation, what financial plans the enterprises prepare and what information is used by enterprises in accounting statements. In relation to it the hypothesis $\mathrm{H} 1$ to $\mathrm{H} 6$ were formulated.

In respect of the person who performs the financial management in the company it was confirmed that the owners take over this function in micro and small companies and that the separate function of financial manager exists in middle and large companies. The research thus has revealed that there are two different groups. The first group includes micro and small companies, financially managed by their owners, or executive manager. The second group covers middle and large companies that have their own financial managers.

As for the most often way of financing it was found that the micro companies most often choose own external capital whereas the small companies do not hesitate to have the majority of foreign capital. Middle companies are equally interested in own as well as foreign capital. And large companies prefer rather their own capital. It results from the research that the foreign capital belongs among the most often ways of financing only for small companies.

As for the investment evaluation it was confirmed that the fact that the company prepares its long-term plan positively influences the fact that it also systematically evaluates its investments. The research has found that $34 \%$ of companies in total do no use any method of investment evaluation. On the contrary, the most often used methods include the payback period (22\%) and the net current value (17\%).

Another point of the research covered the financial plans prepared by companies. It was found that the most often financial plan is the short-term financial plan for 3-12 months. It was confirmed that the larger the companies are, the most they pay attention to their financial planning, for example only $38 \%$ of micro companies prepare their long-term plan. 
The last part of the research was aimed to find out what information from financial statements are the most often used one by companies. As for the balance, all companies, regardless their size, use this statement for their assets management which is right as Brealey and Myers [4] state that the money are generated on the assets' side. As for the profit and loss statement all companies across all their sizes indicated one item of this statement as the most often used information. It means the item of operational costs management. On the contrary, the depreciations as the source of self-financing were the least often used information from the profit and loss statement.

The presented research has confirmed several statements that could be expected nevertheless it also found new information or detailed the current one.

During the research a limiting factor for investment evaluation methods was found. The respondents could also mark in their answers that they use another method. Due to the technical form of the questionnaire it was not possible to detail what method is concerned. With regard to the fact that $12 \%$ of responded marked the answer of another investment evaluation method, it would be surely interesting to find out what other methods are used by companies.

A limitation on the research results could be taken as the fact that no research related to the business field was mentioned in the research. Although the primary intention was to compare the size of the enterprise (in connection with the above) it would be interesting to consider the business aspect for further research as well.

\section{References}

1. ACCA Paper P4. Advanced Financial Management. 3th ed. London: BPP Learning Media, (2009).

2. Accenture, Chartered Institute of Managements Accountants (CIMA). Sustainability performance management: How CFOs can unlock value. CIMA, London (2011).

3. Block, S., Hirt. G.: Foundations of Financial Management, Irwin Burr Ridge, Illinios (1994).

4. Brealey, M., Myers, S. Principles of Corporate Finance. McGraw-Hill, New York (2003).

5. Dluhošová, D. Finanční řízení a rozhodování podniku. 3edn. Ekopress, Praha (2010).

6. Hrdý, M., Krechovská, M.: Podnikové finance v teorii a praxi. 1st edn. Wolters Kluwer ČR, Praha (2013).

7. Hrdý, M., Strouhal, J.: Finanční řizení. 1st edn. Wolters Kluwer ČR, Praha (2010).

8. Jindřichovská, I.: Finanční management. 1st edn. C.H. Beck, Praha (2013).

9. Kanrath, R. Long-term Financing Decision: Views and Practices of Financial Management of NYSE Firms. The Financial Review 2(1997).

10. Kozel, R., Mynářová, L., Svobodová, H. Moderní metody a techniky marketingového výzkumu. Grada Publishing, a. s., Praha (2011).

11. Levy, H., Sarnat, M. Capital Investment and Financial Decisions. $5^{\text {th }}$ edn. Prentice Hall, New Jersey (1994).

12. Marek, L. et al. Statistika pro ekonomy, $2^{\text {nd }}$ edn., Professional Publishing, Praha (2007).

13. Marek, P. et al. Studijní průvodce financemi podniku. Ekopress, Praha (2009).

14. Ross, S. A., Westerfield, R. W., Jaffe, J. Fundementals of Corporate Finance. $7^{\text {th }}$ edn. Mc Graw-Hill, New York (2006). 
15. Saniuk, S. Production orders planning in a network of small and medium-sized enterprises. Contemporary problems in managing production and services supporting manufacturing process. Wydawnictwo Politechniki Lodzkiej, Lodz (2009).

16. Švecová, L., Scholleová, H., Fotr, J. Vybrané aspekty investičního rozhodování (poznatky z empirických výzkumů). E+M. Ekonomie a management. 15(3), (2012).

17. Synek, M. et al.: Podniková ekonomika. 3.edn. C.H. Beck, Praha (2002)

18. Vomáčková, H. Podnik nebo závod obecně a v účetní praxi. Český finanční a účetní časopis. 9(1), 2014.

19. Vyhláška č. 500/2002 Sb. pro podnikatele ve znění pozdějších předpisů.

20. Walker, I.: Výzkumné metody a statistika. Grada Publishing, a. s., Praha (2013).

21. Zákon č. 563/1991 Sb. o účetnictví ve znění pozdějších předpisů. 